\title{
COMPONENTS OF THE FIBRINOLYTIC SYSTEM IN SYNOVIAL JOINTS* \\ NORMAL BOVINE COMPARED WITH NORMAL AND ABNORMAL HUMAN SYNOVIAL JOINTS
}

\author{
BY \\ D. E. CAUGHEY $\dagger$ AND T. C. HIGHTON + \\ Rheumatism Research Laboratories, Wellcome Medical Research Institute, Dunedin, New Zealand
}

Fibrinogen is not normally found in human synovial fluid (Ropes and Bauer, 1953) or in bovine synovial fluid (Cho and Neuhaus, 1960). Normal synovial joints are quite rapidly cleared of fibrin after injury (Harrold, 1961). In rheumatoid arthritis and tuberculous arthritis, fibrinogen entering the joint is precipitated as fibrin and in many cases this is not removed but remains to form fibrin bodies (Fig. 1) or to be incorporated in the inflammatory pannus.

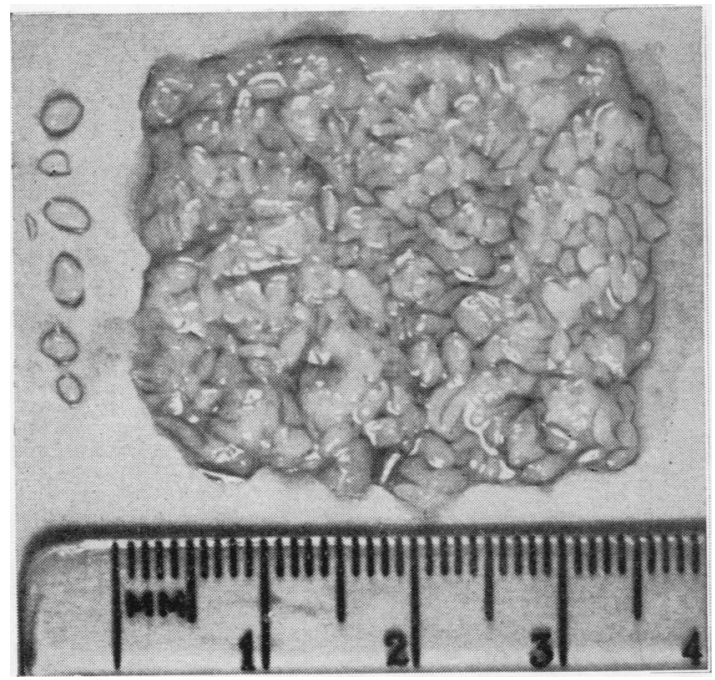

Fig. 1.-Rice bodies removed by aspiration from the knee of a patient with rheumatoid arthritis.

Fibrin is frequently deposited in inflammatory reactions but usually persists for a few days only. Its solution is probably due to plasmin rather than to cellular proteases (Kwaan and Astrup, 1964).

*The work was supported by a grant from the Golden Kiwi Distribution Committee for the promotion of Medical Research.

IIn receipt of the Emily Johnston Research Scholarship.

$\ddagger$ Formerly principal Research Officer of the New Zealand Medical Research Council and now Senior Lecturer in Medicine and Physician in charge of Rheumatic Diseases, Dunedin Public Hospital.
Renewed interest in the role of fibrin in chronic arthritis has been stimulated by Dumonde and Glynn (1962) and Phillips, Kaklamanis, and Glynn (1966). It is suggested that the fibrin which persists at many sites may act as an antigen pool in a disease of disturbed immunity and provide a continuous stimulus to antibody stimulation.

Plasmin, the enzyme, normally involved in removing fibrin, is formed from a $\beta$ globulin, plasminogen, which circulates in the blood and is activated by circulating and tissue activators.

This investigation was performed to establish which of the components of the fibrinolytic system, as they are found in blood and other tissues (Macfarlane 1964), are present in normal synovial joints so that a comparison could be made with the findings in arthritic joints.

Because of the difficulty of obtaining enough normal human synovial fluid without risk of contamination by blood or tissue fluid, synovial fluid from healthy cattle was also examined for components of the fibrinolytic system. Proactivator is not found in the fibrinolytic system of the blood and tissues of cattle, but otherwise the same components are found in cattle as in humans.

\section{Material}

Bovine synovial fluid was examined from twenty different healthy animals aged between 18 months and 3 years. The animals were killed at the local municipal abattoirs and the joints were opened within 10 minutes of death. The knee joints were opened and the cartilage well exposed. No animals were included in which roughening of the joint cartilages was seen. Three fluids were xanthochromic. The usual volume of fluid was 7 to $10 \mathrm{ml}$. Specimens of cartilage and synovial membrane from six different animals were examined for enzymes. The capsule from one joint was examined.

Human synovial fluid was obtained from three normal volunteers aged 28,32 , and 47 years, none of whom had 
joint symptoms. In two specimens minimal bloodstaining occurred and in the third $4 \mathrm{ml}$. clear pale fluid was obtained.

Specimens of synovial membrane, cartilage, and synovial fluid were taken post mortem from five patients who died from disease unrelated to their joints (Table I). In three, no fragmentation of cartilage or villous hypertrophy or synovium was seen when the joints were opened and the fluid was clear and colourless. In two cases the joint was not opened. Two specimens of synovium were obtained at operation on young males for removal of torn menisci from the knee.

Synovial fluid was aspirated from the knees of patients suffering from various inflammatory polyarthritides (Table II, opposite). The fluid was taken into plastic test tubes and plated within an hour (Fig. 2).

Synovial membrane was taken from patients with arthritis at operation, by needle biopsy, or post mortem. The specimens were washed in saline and placed on fibrin plates within an hour (Fig. 3, opposite).
The number of cases and sources of material other than synovial fluid from normal joints are given in Table III (opposite).

\section{Methods}

Synovial fluid was aspirated with plastic syringes and placed in sterile plastic test tubes, and estimations were performed within an hour of aspiration.

Fibrinogen was estimated qualitatively by adding 100 units bovine thrombin in $1 \mathrm{ml}$. normal saline to $1 \mathrm{ml}$. synovial fluid and incubating at $37^{\circ} \mathrm{C}$. for 2 days. A visible clot indicated the presence of fibrinogen (Cho and Neuhaus, 1960). Activator, proactivator, and plasmin and plasminogen were estimated qualitatively on heated and unheated fibrin plates (modified from Flute, 1964).

Bovine fibrinogen (Armour Cohn Fraction I) was reconstituted with Clark and Lub's borate buffer $(0 \cdot 1 \mathrm{M}$ pH 8) containing $0.001 \mathrm{M}$ calcium chloride at a fibrinogen concentration of $300 \mathrm{mg} . / 100 \mathrm{ml}$. buffer and clotted with 10 units of bovine thrombin (Parke Davis and Co.).

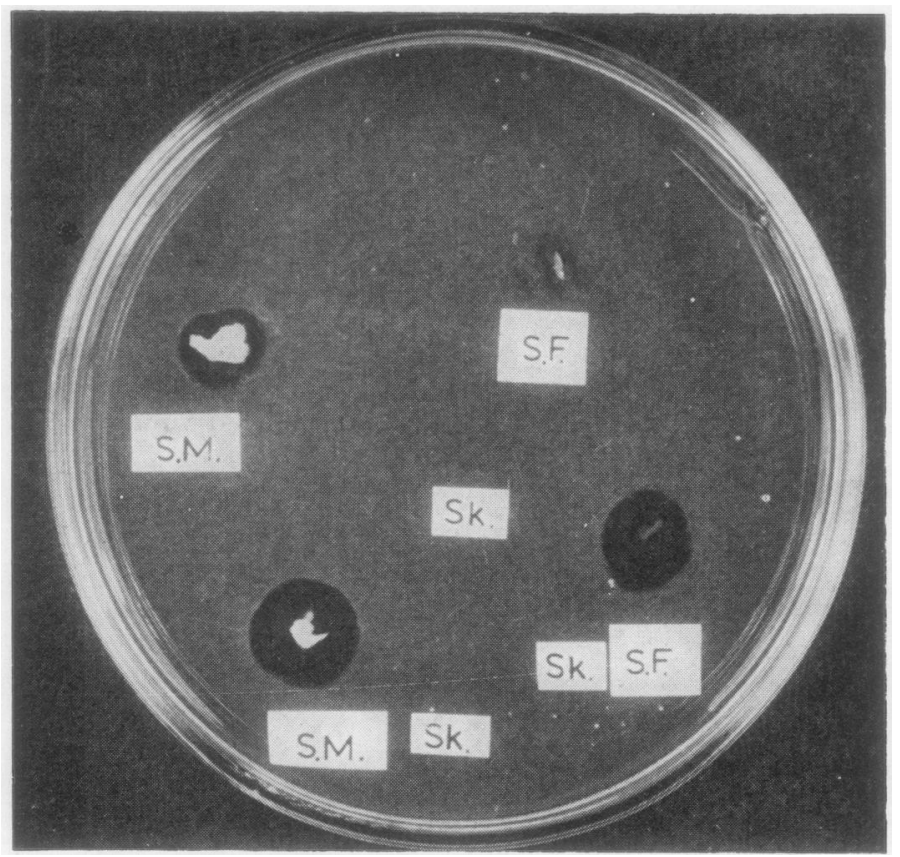

Fig. 2.-Synovial membrane (SM) and synovial fluid (SF) from an osteo-arthritic knee incubated with and without streptokinase (SK) on unheated bovine fibrin. Streptokinase alone produced no digestion. Digestion indicates the presence of proactivator where streptokinase is required, but of activator where digestion occurs without streptokinase.

TABLE I

DETAILS OF CASES EXAMINED POST MORTEM

\begin{tabular}{|c|c|c|c|c|c|c|c|}
\hline \multirow{2}{*}{$\begin{array}{l}\text { Case } \\
\text { No. }\end{array}$} & \multirow{2}{*}{$\begin{array}{l}\text { Age } \\
\text { (yrs) }\end{array}$} & \multirow[b]{2}{*}{ Sex } & \multirow[b]{2}{*}{ Cause of Death } & \multirow{2}{*}{$\underset{\text { Death }}{\text { Hours after }}$} & \multicolumn{3}{|c|}{ Tissue Examined } \\
\hline & & & & & $\begin{array}{c}\text { Synovial } \\
\text { Membrane }\end{array}$ & Cartilage & $\begin{array}{l}\text { Synovial } \\
\text { Fluid }\end{array}$ \\
\hline $\begin{array}{l}1 \\
2 \\
3 \\
4 \\
5\end{array}$ & $\begin{array}{l}18 \\
67 \\
52 \\
44 \\
43\end{array}$ & $\begin{array}{l}\mathbf{F} \\
\mathbf{F} \\
\mathbf{M} \\
\mathbf{F} \\
\mathbf{F}\end{array}$ & $\begin{array}{l}\text { Ventricular fibrillation } \\
\text { Pulmonary embolus } \\
\text { Spinal cord tumour } \\
\text { Cerebral tumour } \\
\text { Asthma }\end{array}$ & $\begin{array}{r}2 \\
6 \\
20 \\
8 \\
14\end{array}$ & $\frac{+}{+}$ & $\frac{ \pm}{ \pm}$ & $\begin{array}{l}+ \\
+ \\
+ \\
+\end{array}$ \\
\hline
\end{tabular}


TABLE II

DIAGNOSIS, NUMBERS OF CASES, AND FIBRINOLYTIC FACTORS FOUND IN 43 SPECIMENS OF SYNOVIAL FLUID

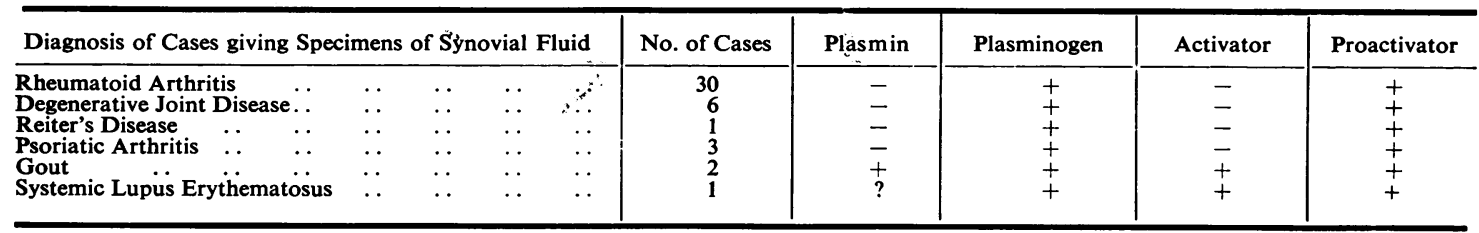

TABLE III

NUMBERS OF SPECIMENS AND SOURCES OF MATERIAL OTHER THAN SYNOVIAL FLUID

\begin{tabular}{|c|c|c|c|c|}
\hline \multicolumn{2}{|c|}{ Diagnosis } & Source of Material & Synovial Membrane & Cartilage \\
\hline Rheumatoid Arthritis & $\begin{array}{l}1 \\
2 \\
3 \\
4 \\
5\end{array}$ & $\begin{array}{l}\text { Synovectomy } \\
\text { Synovectomy } \\
\text { Synovectomy } \\
\text { Synovectomy } \\
\text { Meniscectomy }\end{array}$ & $\begin{array}{l}+* \\
+ \\
+ \\
+ \\
+\end{array}$ & $\begin{array}{l}\overline{ } \\
\pm \\
-\end{array}$ \\
\hline Osteo-arthritis & $\begin{array}{l}1 \\
2\end{array}$ & $\begin{array}{l}\text { Post mortem } \\
\text { Post mortem }\end{array}$ & $\begin{array}{l}+^{*} \\
+^{*}\end{array}$ & + \\
\hline
\end{tabular}

+Indicates material was obtained. All specimens contained activator.

* Minimal digestion occurred on heated plates.

Fig. 3.-An "unheated" bovine fibrin film containing plasminogen. Digestion around specimens of human bone, cartilage, and synovial membrane after incubation at $37^{\circ} \mathrm{C}$. for 20 hours. The failure of these tissues to produce digestion on a heated fibrin film illustrates that activator and not plasmin is present in these tissues.

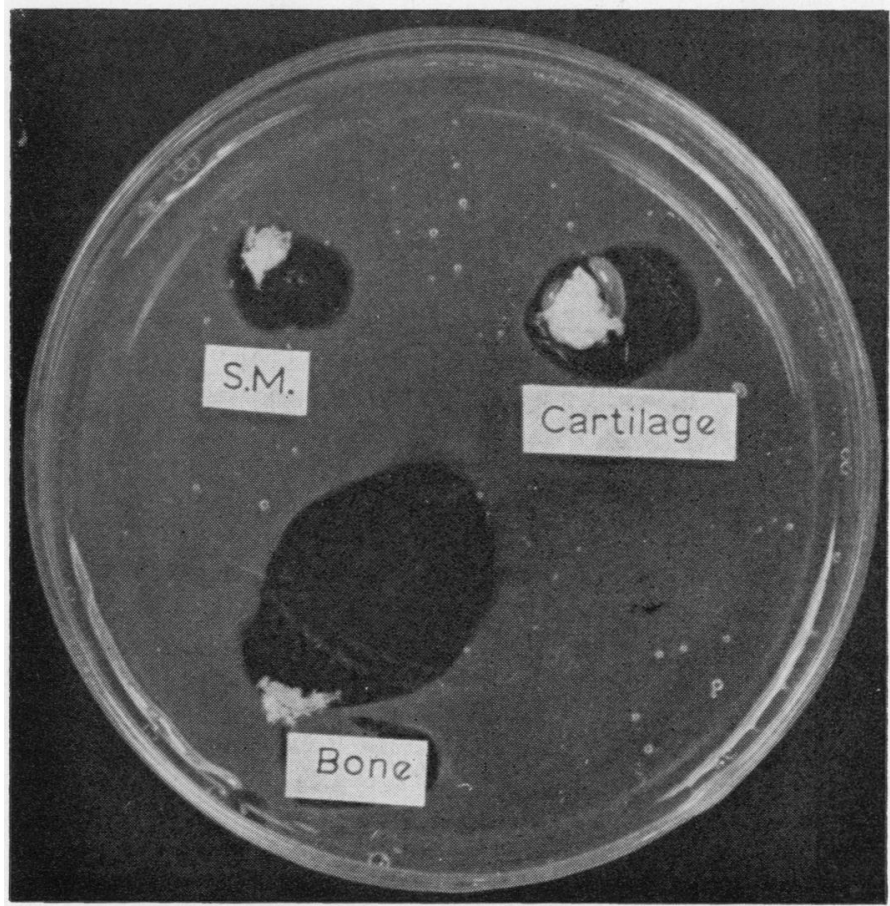

Heated plates were placed in an oven at $95^{\circ} \mathrm{C}$. for 35 minutes and on cooling they were tested with the activator urokinase (400 units/ml.) (Leo), to be certain that no digestion occurred and thus confirm that plasminogen had been destroyed by the heating.

Synovial fluid, capsule, or saline-washed portions of cartilage and synovial membrane were placed on the plates with and without the addition of streptokinase
(100 units/ml.) (Lederle) (Fig. 3). The plates were incubated for $20 \mathrm{hrs}$ and the presence or absence of digestion of the fibrin film noted after this time.

The snap-frozen piece of synovium taken from the fifth case of rheumatoid arthritis was sectioned and the tissue incubated on a film of bovine fibrin at $37^{\circ} \mathrm{C}$. This preparation was then stained with Mayer's haemalum (Todd, 1964) (Fig. 4, overleaf). 


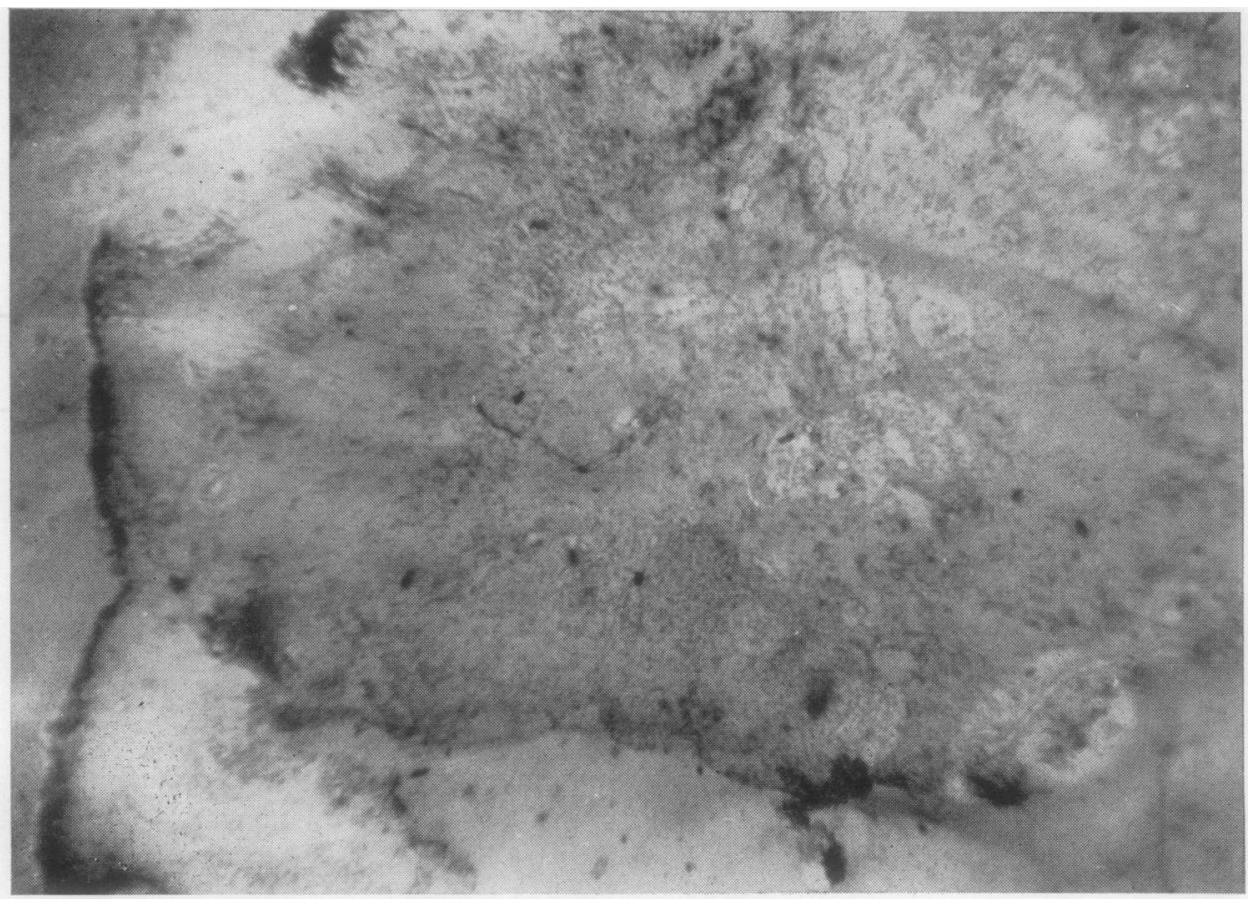

Fig. 4.-Areas of digestion of a bovine fibrin film seen as pale areas around blood vessels in a frozen section of synovial membrane from a case of rheumatoid arthritis.

\section{Results}

\section{Normal Synovial Fluid}

Bovine.-All of twenty specimens were examined for proactivator, activator, and plasmin, and none was found. The twelve examined for plasminogen all contained it. This included three specimens that were xanthochromic. The three xanthochromic specimens were the only ones containing fibrinogen.

Human.-All eight specimens contained proactivator and plasminogen, and only one contained a small amount of activator. No specimen contained plasmin. No specimen was sufficiently large to estimate fibrinogen.

\section{Normal Synovial Membrane}

Bovine.-All of eight specimens contained activator but no plasmin.

Human.-The two specimens obtained at meniscectomy and three specimens obtained post mortem contained activator but none contained plasmin. An assessment of proactivator was made in synovial fluid only.

\section{Normal Cartilage}

Bovine.-All of eight specimens contained activator.
Human.-All of three specimens contained activator.

\section{Normal Capsule}

Bovine.-The one specimen examined contained activator.

Human.-The one specimen examined contained activator.

\section{Abnormal Synovial Fluid}

The results are summarized in Table IV (opposite).

Plasminogen and proactivator were present in the diseased joints examined and qualitatively there was no difference between normal synovial fluid and that from patients with rheumatoid arthritis, degenerative joint disease, psoriatic arthritis, or Reiter's disease in this respect.

The two specimens of gouty fluid, however, contained plasmin and these were carefully checked on heated plates with urokinase control (Fig. 5, opposite).

Fibrinogen was present in the synovial fluid from all diseased joints, which thus differed from normal joints. Such specimens of synovial membrane and cartilage as were examined (Table III) showed the 
TABLE IV

SUMMARY OF QUANTITATIVE RESULTS

\begin{tabular}{|c|c|c|c|c|c|c|c|c|c|}
\hline \multicolumn{5}{|c|}{ Type of Specimen } & No. of Specimens & Plasmin & Plasminogen & Activator & Proactivator \\
\hline \multirow[t]{3}{*}{ Human } & Synovial Fl & $\cdots$ & . & . & 8 & - & + & - & + \\
\hline & Synovial M & ane & . & $\cdots$ & 5 & - & - & + & - \\
\hline & Cartilage & $\cdots$ & . & $\cdots$ & 3 & - & - & + & - \\
\hline \multirow[t]{4}{*}{ Bovine } & Synovial Fl & $\cdots$ & . & $\cdots$ & 20 & - & $+*$ & - & - \\
\hline & Synovial M & ane & . & $\ldots$ & 8 & - & - & + & - \\
\hline & Cartilage . & $\cdots$ & . & $\cdots$ & 8 & - & & + & 一 \\
\hline & Capsule . & .. & .. & $\ldots$ & 1 & - & - & + & - \\
\hline
\end{tabular}

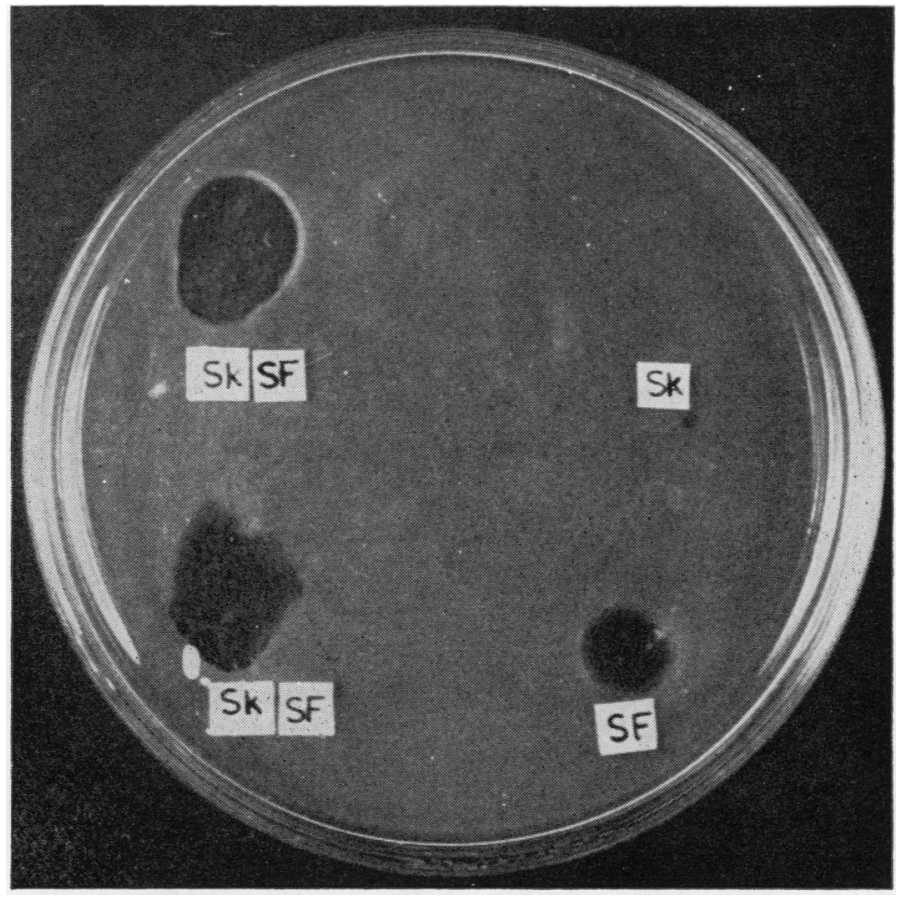

presence of activator. No direct test for proactivator was made, although in several cases the amount of digestion was greater around tissue to which streptokinase had been added, suggesting the presence of proactivator.

Those specimens in Table III marked with an asterisk produced minimal digestion on heated plates, suggesting that plasminogen was present in these specimens, possibly contaminated by blood, or that the plasminogen in the plates was not completely heat inactivated. This was not seen in subsequent work when a urokinase control was used and plasminogen was shown to be completely inactivated. However, the additional heating of the fibrin makes it less digestible by plasmin and the heated plates less able to detect small quantities of plasmin.

\section{Discussion}

Previous studies have been made on fibrinolytic factors in human joints. Albrechtson, Storm, and Claassen (1958), examining synovial fluid from patients with "non-inflammatory effusions" (they did not further define these), found plasminogen and proactivator but no plasmin. Lack (1959) stated that plasmin inhibitors were present in normal synovial fluid and demonstrated the presence of 
tissue activator in normal cartilage. Astrup and Sjølin (1958) showed tissue activator to be present in synovial membrane of patients who died from diseases unrelated to their joints and noted the very low concentrations of tissue thromboplastin in normal human joint tissues. We could find no reports of studies of fibrinolytic factors in bovine joints.

Factors influencing synovial membrane permeability are complex. Ogston and Phelps (1961) stressed the probable role of hyaluronic acid in excluding proteins of certain sizes and shapes.

We have found plasminogen in synovial fluid of normal cattle and normal human subjects. When these experiments were being performed the molecular weight of plasminogen was thought to be 143,000 (Shulman, Alkjaersig, and Sherry, 1958), but the work of Robbins, Summaria, Elwyn, and Barlow (1965) has shown it to be $89,000 \pm 1,500$ which explains its presence in normal synovial fluid, which we at first thought remarkable. The presence of proactivator and absence of activator in normal human synovial fluid is confirmed. No estimates of antiactivator or plasmin inhibitors was made, but the use of plastic containers (Flute, 1964) should have reduced the amount of antiactivator formed in vitro.

Activator, although absent from normal synovial fluid, is present in normal synovial membrane and in normal cartilage. Thus, in the normal joint, all components of the fibrinolytic system are present to produce free plasmin unless they are inhibited by anti-enzymes or unless antiplasmin is present in quantity.

Harrold (1961) suggested that when fibrinogen entered the joint it became the substrate for two competing reactions: either conversion to fibrin by thrombin, or fibinogenolysis by plasmin. The speed at which blood enters the joint may influence which reaction takes place, but a slow ooze would favour fibinogenolysis and no clot would form. Harrold suggested that the joint was kept free of clots in this way.

An alternative view would be that with a haemarthrosis blood enters the joint, a clot forms with plasminogen from either blood or synovial fluid incorporated in it, and the tissue activator in normal synovium is enough to activate this to plasmin and to produce digestion of the clot.

Further studies are needed to determine if there are factors released during traumatic haemarthrosis which could be responsible for the formation of activator from the proactivator in normal human synovial fluid.
Chakrabarti, Fearnley, and Hocking (1964) found the blood fibrinolytic activity to be decreased in rheumatoid arthritis and to be increased by treatment with corticosteroids.

It was thought that this examination might reveal an absence of one of the fibrinolytic factors within the joint to account for fibrin persistence in rheumatoid arthritis but none was found. The presence of plasmin in gouty fluid was unexpected in 1964, but is now of great theoretical interest in view of the work of Kellermeyer and Breckenridge (1965), who noted the ability of urate crystals to activate Hageman factor. Kellermeyer and Breckenridge (1966) have since shown that plasma thromboplastin antecedent and Hageman factor are present in normal synovial fluid in primarily the inactive form, in concentrations comparable to those found in plasma. It is known that Hageman factor can activate plasminogen (Eisen, 1964, 1966) to plasmin, a proteolytic enzyme which can split the painproducing substances kinin and kallekrein from their precursor polypeptides. Plasmin has not to our knowledge been previously described in gouty synovial fluid and although this finding is confined to only two cases, it fits very well the hypothesis put forward by Eisen (1966) to explain part of the mechanism for the acute gouty attack,

The role of the plasmin system in producing cartilage destruction in bacterial arthritis has been elaborated by Lack and Rogers (1958). Lack stated that tuberculous tissue had a high content of plasmin inhibitor to explain the persistence of fibrin and slow destruction of cartilage.

One is loth to accept the idea that an excess of a normally occurring enzyme accounts for inhibition, but possibly some product of tuberculous inflammation has the power to inhibit fibrinolysis.

In testing rheumatoid synovial fluid, an extrinsic lysokinase, streptokinase, had to be added to form activator. However, activator is contained in cells and, if the cells of an inflammatory effusion are concentrated by centrifugation and added to a drop of the fluid, digestion occurs (Fig. 6, opposite), indicating the presence of activator in the cells, or possibly the presence of protease released from the lysozomes of disrupted cells in the synovial fluid (Lack, 1959; Dingle, 1965).

That activator is present in synovial membrane, the seat of inflammation, and can dissolve preformed human fibrin can be demonstrated by the incubation of a frozen section of synovial membrane on a fibrin film (Todd, 1959). After incubation the preparation is stained and the area of digestion demonstrates the site of plasmin formation with 
Fig. 6.-Area of digestion on unheated fibrin around centrifuged cells from the synovial fluid of a patient with rheumatoid arthritis. This indicates the presence of activator or a cellular protease.

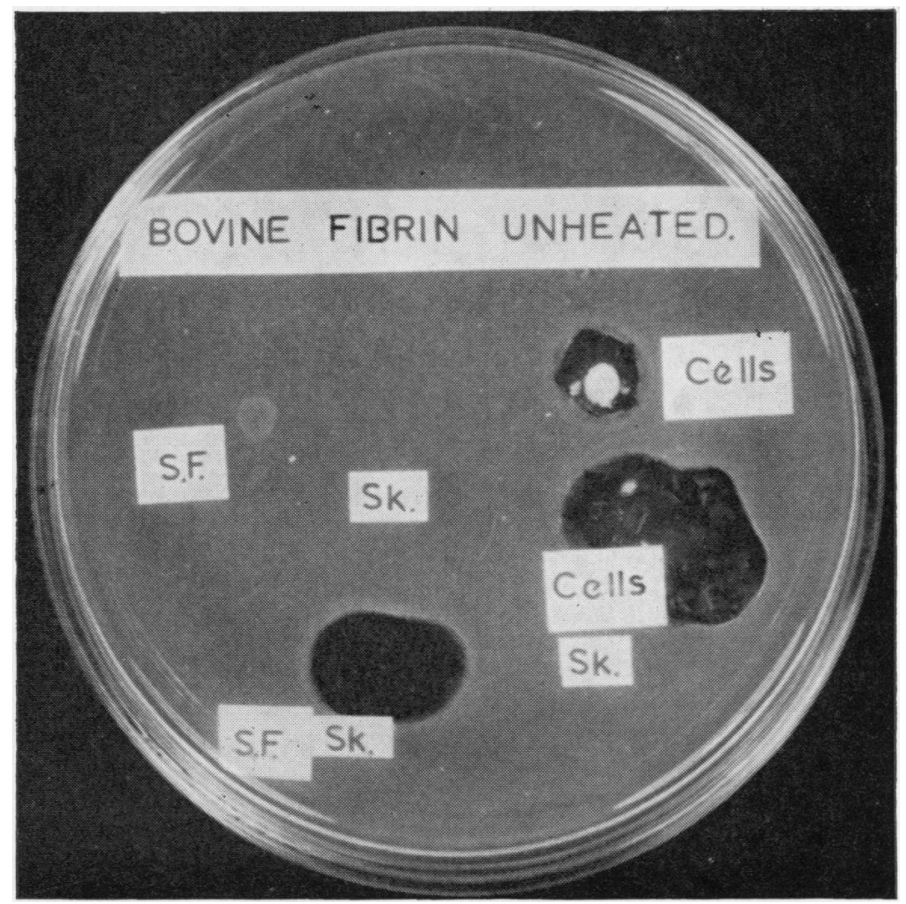

subsequent digestion of the fibrin. The specimen in Fig. 4 was taken at meniscectomy for a torn cartilage, but histological examination revealed chronic inflammatory changes consistent with rheumatoid arthritis, and areas of digestion are seen around small vessels. Studies are in progress to determine whether normal synovial cells have activator activity in order to compare them with rheumatoid synovial cells.

Activator is present in synovial membrane, probably mainly in the small vessels. It is possibly present in the leucocytes of the exudate, although the active substance in leucocytes may be some other protease. Activator is thus locally available to form plasmin from plasminogen.

Fibrin persistence might be due to the overcoming of the fibrinolytic system by frequent small haemorrhages into the joint, reduced amounts of plasminogen compared with normal joint fluid, or an excess of plasmin inhibitor. Such indirect evidence as we have does not point to an excess of fibrinstabilizing factor. The combination of fibrin with some product of the inflammatory reaction which renders it resistant to plasmin was a further possibility (Lack, 1964), but in fact the fibrin was found to be soluble.

Although fibrin persistence is of interest in terms of its possible role as an antigen in rheumatoid arthritis, it is not confined to rheumatoid arthritis but is also found in tuberculosis. Thus, if one is to suggest a central role for fibrin as an antigen in rheumatoid arthritis, one must say that it is not only the persistence of fibrin but also the disturbed immunological mechanisms which are at fault.

\section{Summary}

Qualitative studies of the components of the fibrinolytic system as they exist in diseased joints have been made to compare with the findings in normal joints in an endeavour to explain the persistence of fibrin in rheumatoid arthritis.

Plasminogen and proactivator were found in normal and abnormal human synovial fluid. Activator was found in the cartilage, synovial membrane, and capsule of normal and abnormal human joints and normal bovine tissues. Fibrinogen was present in the synovial fluid of diseased joints, but not in normal joint fluid. Plasminogen but no proactivator was present in bovine synovial fluid.

The finding of plasmin in two gouty joints was unexpected but fits in well with a concept recently put forward to explain the mechanism of the acute attack of gout.

The role of the fibrinolytic system in traumatic haemarthrosis and in chronic arthritis where fibrin persists is briefly discussed. 
The authors are grateful for the technical assistance of Mrs. M. Garrett, B.Sc., Mrs. J. Meldrum, and Mrs. L. Bratt.

\section{REFERENCES}

Albrechtsen, C. K., Storm, O., and Claassen, M. (1958). Scand. J. clin. Lab. Invest., 10, 310 (Fibrinolytic activity in some human body fluids).

Astrup, T., and Sjølin, K. E. (1958). Proc. Soc. exp. Biol. (N.Y.), 97, 852 (Thromboplastic and fibrinolytic activity of human synovial membrane and fibrous capsular tissue).

Chakrabarti, R., Fearnley, G. R., and Hocking, E. D. (1964). Brit. med. J., 1, 534 (Effect of corticosteroid therapy on fibrinolysis in patients with inflammatory and non-inflammatory conditions).

Cho, M. H., and Neuhaus, O. W. (1960). Thromb. Diath. Haemorrh., 5, 108 (Absence of blood clotting substances from synovial fluid).

Dingle, J. T. (1965). In "Second Nuffield Conference on Rheumatism, Tring, 1964", p. 75 [Typescript] (The role of degenerative enzymes).

Dumonde, D. C., and Glynn, L. E. (1962). Brit. J. exp. Path., 43, 373 (The production of arthritis in rabbits by an immunological reaction to fibrin).

Eisen, V. (1966). Proc. roy. Soc. Med., 59, 302 (Urates and kinin formation in synovial fluid).

- (1964). Brit. med. Bull., 20, 205 (Fibrinolysis and formation of biologically active polypeptides).

Flute, P. T. (1964). Ibid., 20, 195 (The assessment of fibrinolytic activity in the blood).

Harrold, A. J. (1961). J. clin. Path., 14, 305 (The defect of blood coagulation in joints).

Kellermeyer, R. W., and Breckenridge, R. T. (1965). J. Lab. clin. Med., 65, 307 (The inflammatory process in acute gouty arthritis. I. Activation of Hageman factor by sodium urate crystals).

—, (1966). Ibid., 67, 455 (The inflammatory process in acute gouty arthritis. II. The presence of Hageman factor and plasma thromboplastin antecedent in synovial fluid).

Kwaan, H. C., and Astrup, T. (1964). J. Path. Bact., 87, 409 (Fibrinolytic activity of reparative connective tissue).

Lack, C. H. (1959). J. Bone Jt Surg., 41B, 384 (Chondrolysis in arthritis).

- (1964). Brit. med. Bull., 20, 217 (Proteolytic activity and connective tissue).

_ and Rogers, H. J. (1958). Nature (Lond.), 182, 948 (Action of plasmin on cartilage).

Macfarlane, R. G. (1964). Ibid., 20, 173 (The development of ideas on fibrinolysis).

Ogston, A. G., and Phelps, C. F. (1961). Biochem. J., 78, 827 (The partition of solutes between buffer solutions and solutions containing hyaluronic acid).

Phillips, J. M., Kaklamanis, P., and Glynn, L. E. (1966). Ann. rheum. Dis., 25, 165 (Experimental arthritis associated with auto-immunization to inflammatory exudates).

Robbins, K. C., Summaria, L., Elwyn, D., and Barlow, G. H. (1965). J. biol. Chem., 240, 541 (Further studies on the purification and characterization of human plasminogen and plasmin).

Ropes, M. W., and Bauer, W. (1953). "Synovial Fluid Changes in Joint Disease”, p. 52. Harvard University Press, Cambridge, Mass.

Shulman, S., Alkjaersig, N., and Sherry, S. (1958). J. biol. Chem., 233, 91 (Physicochemical studies on human plasminogen [profibrinolysin] and plasmin [fibrinolysin] ).

Todd, A. S. (1959). J. Path. Bact., 78, 281 (The histological localization of fibrinolysin activator).

- (1964). Brit. med. Bull., 20, 210 (Localization of fibrinolytic activity in tissues). 
Les composants du systéme fibrinolytique dans les articulations synoviales

Une comparaison entre les articulations synoviales bovine et humaine, normale et anormale

\section{RÉSUMÉ}

On a procédé à des études qualitatives des composants du système fibrinolytique des articulations malades et normales pour trouver l'explication de la persistence de la fibrine dans l'arthrite rhumatismale.

Le plasminogène et un proactivateur furent trouvés dans le liquide synovial humain normal et anormal. L'activateur fut trouvé dans le cartilage, la membrane synoviale et dans la capsule des articulations humaines normales et anormales et dans les tissus bovins normaux. On nota la présence de fibrinogène dans le liquide synovial des articulations malades, mais non pas dans le liquide articulaire normal.

La présence de la plasmine dans deux articulations goutteuses fut surprenante mais elle s'accorde bien avec une conception récemment énoncée pour expliquer le mécanisme d'une attaque aiguë de goutte.

On discute brièvement le rôle du système fibrinolytique dans l'hémarthrose traumatique et dans l'arthrite chronique où la fibrine tend à persister.
Los componentes del sistema fibrinolítico en las articulaciones sinoviales

Estudio comparativo de las articulaciones sinoviales bovina y humana, normal y anormal

\section{SUMARIO}

Se estudiaron cualitativamente los componentes del sistema fibrinolítico en articulaciones enfermas y normales para hallar una explicación de la persistencia de la fibrina en la artritis reumatoide.

El plasminógeneo y un proactivador fueron encontrados en el líquido sinovial humano normal y anormal. El activador fué hallado en el cartílago, la membrana sinovial y en la cápsula de las articulaciones humanas normales y anormales y en los tejidos bovinos normales. Se notó la presencia de fibrinógeno en el líquido sinovial de articulaciones enfermas pero no de las sanas.

La presencia de la plasmina en dos articulaciones gotosas fué inesperada pero se acuerda con un concepto reciente del mecanismo del ataque agudo de gota.

Se discute en breve el papel del sistema fibrinolítico en la hemartrosis traumática y en la artritis crónica en las cuales la fibrina tiende a persistir. 